CENTRE FOR ECONOMIC PERFORMANCE DISCUSSION PAPER NO. 293

March 1996

\title{
COMBATTING UNEMPLOYMENT:
} IS FLEXIBILITY ENOUGH?

R.JACKMAN, R. LAYARD AND S. NICKELL 


\section{ABSTRACT}

Our conclusions are that the most important influences on unemployment come from the following.

(i) The longer unemployment benefits are available the longer unemployment lasts. Similarly, higher levels of benefits generate higher unemployment, with an elasticity of around one half. On the other hand active help in finding work can reduce unemployment. So more "flexibility" may need to be complemented by more intervention to provide active help.

(ii) Union coverage and union power raise unemployment. But if wage bargaining is decentralised, wage bargainers have incentives to settle for more than the "going rate", and only higher unemployment can prevent them leap-frogging. Although decentralisation makes it easier to vary relative wages, this advantage is more than offset by the extra upward pressure on the general level of wages. Thus, where union coverage is high, coordinated wage bargaining leads to lower unemployment.

(iii) Conscious intervention to raise the skill levels of less able workers is an important component of any policy to combat unemployment. Pure wage flexibility may not be sufficient because it leads to growing inequality which in turn discourages labour supply from less able workers.

Thus in these areas it is clear what types of reform are needed. If well designed, such reforms might halve the level of unemployment in many countries.

But there are three other remedies which have been widely advocated in both the OECD Jobs Study and the Delors White Paper. These are: less employment protection, lower taxes on employment, and lower working hours. Our research does not suggest that lower employment taxes or lower hours would have any long term effects; while the effects of lower employment protection would be small.

(iv) Lower employment protection has two effects. It increases hiring and thus reduces long-term unemployment. But it also increases firing and thus increases short-term unemployment. The first (good) effect is almost offset by the second (bad) one. The gains from flexibility are small.

(v) Employment taxes do not appear to have any long-term effect on unemployment and are borne entirely by labour. There may be some shortterm effects, but it is not clear that there would be any fall in inflationary pressure if taxes on polluting products were raised at the same time as taxes on employment were lowered.

(vi) Hours of work appear to have no long-term effect upon unemployment. Equally, if early retirement is used in order to reduce labour supply, it is necessary to reduce employment pari passu unless inflationary pressure is to increase. While flexible hours and participation can reduce the fluctuations in unemployment over the cycle, they cannot affect its average level.

This paper was produced as part of the Centre's

Programme on Human Resources 


\section{COMBATTING UNEMPLOYMENT:}

IS FLEXIBILITY ENOUGH?

R. Jackman, R. Layard and S. Nickell 


\section{MARCH 1996}

Published by

Centre for Economic Performance

London School of Economics and Political Science

Houghton Street

London

WC2A $2 \mathrm{AE}$

CR.Jackman, R.Layard and S. Nickell, 1996

ISBN 0753005395 


\section{COMBATTING UNEMPLOYMENT: IS FLEXIBILITY ENOUGH?}

R. Jackman, R. Layard and S. Nickell

Page

1. Country differences

2. Policies to the unemployed 5

3. Wage bargaining 10

4. Skills imbalance 12

5. Employment protection 15

6. Taxes on employment 22

7. Work-sharing and early retirement 26

8. Conclusions 29

Endnotes 31

Tables $\quad 35$

Figures $\quad 46$

References 48 
The Centre for Economic Performance is financed by the Economic and Social Reserach Council.

Paper for the OECD Conference on 'Interactions between Structural Reform, Macroeconomic Policies and Economic Performance', Paris, 18th-19th January 1996. 


\title{
COMBATTING UNEMPLOYMENT: IS FLEXIBILITY ENOUGH?
}

\author{
R. Jackman, R. Layard, S. Nickell ${ }^{1}$
}

What is the route to lower unemployment? Is it through greater labour market flexibility, involving deregulation and decentralisation? Or are there areas where more collective action, rather than less, is required?

To examine this issue we have tried to see how differences of policy and institutions affect the unemployment levels in the different OECD countries. (We are concerned not with cyclical fluctuations but with the average levels of unemployment over a run of years.) The factors whose possible influence we examine are:

(i) how unemployed people are treated (benefit levels and active help with job-finding);

(ii) how wages are determined;

(iii) how skills are formed;

(iv) how far jobs are protected by redundancy legislation;

(v) how heavily employment is taxed, and

(vi) how far labour supply is reduced through reductions in hours of work and through early retirement.

Our conclusions are that the most important influences on unemployment come from the following.

(i) The longer unemployment benefits are available the longer unemployment lasts. Similarly, higher levels of benefits generate higher unemployment, with an elasticity of around one half. On the other hand active help in finding work can reduce unemployment. So more "flexibility" may need to be complemented by more intervention to provide active help.

(ii) Union coverage and union power raise unemployment. But if wage bargaining is decentralised, wage bargainers have 
incentives to settle for more than the "going rate", and only higher unemployment can prevent them leap-frogging. Although decentralisation makes it easier to vary relative wages, this advantage is more than offset by the extra upward pressure on the general level of wages. Thus, where union coverage is high, coordinated wage bargaining leads to lower unemployment.

(iii) Conscious intervention to raise the skill levels of less able workers is an important component of any policy to combat unemployment. Pure wage flexibility may not be sufficient because it leads to growing inequality which in turn discourages labour supply from less able workers.

Thus in these areas it is clear what types of reform are needed. If well designed, such reforms might halve the level of unemployment in many countries.

But there are other remedies which have been widely advocated (some of them in the OECD Jobs Study and/or the Delors White Paper). These include: less employment protection, lower taxes on employment, and lower working hours. Our research does not suggest that lower employment taxes or lower hours would have any long term effects; while the effects of lower employment protection would be small.

(iv) Lower employment protection has two effects. It increases hiring and thus reduces long-term unemployment. But it also increases firing and thus increases short-term unemployment. The first (good) effect is almost offset by the second (bad) one. The gains from flexibility are small.

(v) Employment taxes do not appear to have any long-term effect on unemployment and are borne entirely by labour. There may be some short-term effects, but it is not clear that there would be any fall in inflationary pressure if taxes on polluting products were raised at the same time as taxes on employment were lowered. 
(vi) Hours of work appear to have no long-term effect upon unemployment. Equally, if early retirement is used in order to reduce labour supply, it is necessary to reduce employment pari passu unless inflationary pressure is to increase. While flexible hours and participation can reduce the fluctuations in unemployment over the cycle, they cannot affect its average level.

We can now proceed to the evidence for these assertions. We begin by looking at the pattern of unemployment differences between countries and estimate an equation which explains it, using all the factors we find significant. We then discuss each factor in turn, drawing on other evidence where relevant. We end with policy conclusions.

\section{COUNTRY DIFFERENCES}

There are wide differences in unemployment rates across countries, but one feature of these differences has been little noticed: a large part of the variation is in long-term unemployment. This is shown in Table 1. It appears that countries can live with very different rates of long-term unemployment, whereas some short-term unemployment seems inevitable. The reason for this "optional" nature of long-term unemployment appears to be that long-term unemployment has a much lower effect on wage pressure than does short-term unemployment (OECD 1993, p.94).

To explain unemployment it is therefore useful to explain separately not only the total of unemployment but also its two different parts (short-term and long-term). We shall explain unemployment rates in 1983-8 and 1989-94, using the following main explanatory variables:

Replacement rate (\%)

Benefit duration (years; indefinite $=4$ years) 
Active labour market policy per unemployed person as \% of output per worker (ALMP)

Union coverage (1 under 25\%, 2 middle, 3 over $75 \%$ )

Coordination in wage bargaining ( 1 low, 2 middle, 3 high)

Employment protection (ranking: 1 low, 20 high)

Change in inflation (percentage points per annum).

The last variable is included because it is always possible to achieve a temporary fall in unemployment through allowing inflation to increase. ${ }^{2}$ The values of the variables are in Table 2.

The explanatory regression was a pooled regression for the two sub-periods. (We checked that the two sets of coefficients in the two sub-periods were not as a set significantly different.) The results are in Table 3. In the equation for long-term unemployment we also include short-term unemployment as a regressor.

OECD countries do of course display quite severe persistence in unemployment, and our two six-year periods may not be long enough to eliminate these effects. ${ }^{3}$ However, terms measuring lagged unemployment were either insignificant or incorrectly signed, and have therefore not been included. The pooled regression was however estimated by the random-effects method which to some extent discounts the effects of persistent country specific factors.

Turning to our results, we can first explain the cross-country variation of long-term unemployment. All the variables reflecting the treatment of unemployed people come in with the predicted sign. The system of wage bargaining is also important. Employment protection raises long-term unemployment.

However when we turn to short-term unemployment, things change. Not surprisingly, benefit duration and active labour market policy (ALMP) are unimportant. And, as expected, employment protection reduces short-term unemployment, by reducing the inflow to unemployment.

Turning to the effects on total unemployment, employment protection has an insignificant effect. But unemployment does respond 
to how unemployed people are treated and to how wages are determined.

To understand why all these variables might affect unemployment, we need to see how they fit into an integrated framework. This is provided by the system of wage and price equations. Assuming no price surprises, we have

Wage equation

$$
\log W^{\prime} \& ? \log (c u) \%
$$

Price equation (simplified)

$$
\log W^{\prime} \beta \% \operatorname{og}(Y / L)
$$

where $\mathrm{W}$ is the real cost per worker, $\mathrm{u}$ the unemployment rate, $\mathrm{c}$ the "effectiveness" of the unemployed, $Z$ the impact of other wage pressure variables, and Y/L is output per head of labour force.

Thus the equilibrium unemployment rate is given by

$$
\log (c u)^{\prime} \frac{Z \& B}{?} \text {. }
$$

The key variables affecting unemployment are those which affect "wage pressure" (namely c and the Zs) plus the effect of unemployment in offsetting wage pressure (?). We can now examine each of the possible causes of unemployment for their effect on wage pressure.

\section{POLICIES TO THE UNEMPLOYED}

\section{Benefits}


Benefits work through two mechanisms. First, they reduce the fear of unemployment and thus directly increase wage pressure from the unions (a simple $\mathrm{Z}$ factor). But second, and more important, they reduce the 'effectiveness' of unemployed people (c) as fillers of vacancies. This encourages employers to raise wages. It also reduces the competition which newly unemployed workers will face in their search for jobs, which again encourages the unions to push for higher wages.

Since any reduction in effectiveness (c) leads to an equiproportional increase in unemployment, one can obtain an estimate of the effects of benefits (working through c) from micro cross-sectional studies which explain exit rates by benefits, holding vacancies constant. These estimates typically give an elasticity of exit rates with respect to the replacement ratio of around one half, with a wide range on either side (Narendranathan et al., 1985; Atkinson and Micklewright 1991).

A second key dimension of unemployment benefits is their potential duration. Long-term benefits increase long-term unemployment. There are two processes at work here. First benefits reduce exit rates in general. But the resulting long-term unemployment further reduces exit rates. For in those countries where long-term unemployment is common, the exit rates for the long-term unemployed are much lower than for the short-term unemployed - in other words they have lower c. At least in part this appears to reflect a statedependence of exit rates on duration (Jackman and Layard, 1991). Thus the incidence of long-term unemployment shifts out the U/V curve in many European countries (Budd, Levine and Smith, 1988).

However when unemployment benefits run out quite quickly exit rates decline much less as duration lengthens. This is confirmed by Meyer and Katz (1991) and Carling et al., (1995) for the US and Sweden, where benefits run out after 6 and 14 months respectively. By contrast in Britain and Australia, where benefits are long-lived, there is much more state dependence. (Jackman and Layard, 1991; Fahrer and Pease, 1993.) 


\section{Active labour market policies (ALMP)}

If long-duration benefits have negative effects, one approach is simply to provide no help to unemployed people beyond some period. Given sufficient wage flexibility, this will increase employment. But the cost will be more unequal wages, and not all of long-term unemployment will be eliminated.

An alternative is to provide some help to all who do not get benefit, but to give it through activity rather than though benefits. This cuts off the flow of long-term unemployment at least for the period for which the active measures last, and gives all the unemployed at least a chance to prove themselves.

This latter alternative is the Swedish model: active labour market policy replaces benefits. It should be sharply distinguished from other systems of active labour market policy where the uptake of the help offered is voluntary, so that labour market activity is an optional alternative to benefits. While active labour market policies of the second kind do continue in many countries, there is an interesting shift towards the Swedish model in Switzerland, while Denmark which has always had a similar general approach to Sweden's has now shortened the "passive" period of benefit duration to 2 years (Schwanse, 1995). In our regression equation, we find that dropping Sweden eliminates the effect of active labour market policy spending on long-term unemployment, consistent with the view that only Swedish-style ALMPs make a real difference.

The case for active labour market policy comes of course from social cost-benefit analysis. But it is also important to note that in terms of costs and benefits to the Ministry of Finance, optional ALMP is quite costly per unit reduction in unemployment, since those helped by the subsidy will include a disproportionate number of people who would have exited anyway (the problem of 'deadweight'). Replacement ALMP can more nearly break-even, since all of those still unemployed are helped; there is thus a known maximum for the proportion of those helped who would have exited otherwise (the problem of "deadweight" is reduced, through avoiding creaming). 
The other problem with active labour market policy is "substitution and displacement" - if an employer employs someone who would not have exited otherwise, this may disemploy someone else who would otherwise have been employed. In normal discussions this problem is greatly exaggerated. For the aim of ALMP is to help people who would otherwise have had low exit probabilities. By positive discrimination in their favour, vacancies go to them rather than to others who had better exit probabilities (were more employable). The effect is to increase the total stock of employable workers who are still unemployed. So vacancies get filled faster and employment expands. By helping the hard to place, the total stock of employable labour expands. In response the total stock of jobs expands.

We can easily see this in the context of our model - equations (1) and (2). There is a certain required level of cu. Through the active labour market policy the average effectiveness of the unemployed (c) is increased. This decreases wage pressure at each level of unemployment (see Figure 1). In consequence there is an increase in the equilibrium employment rate. Assuming that when prices are set the mark-up of prices over wages is constant, as in Figure 1, unemployment falls by the same proportion that average effectiveness (c) rises.

But what about substitution and displacement? If for example action is taken to help the long-term unemployed, does this increase short-term unemployment? The logic of our model says No.

Suppose the short-term unemployed have effectiveness $\mathrm{c}_{\mathrm{s}}$ and the long-term unemployed have effectiveness $c_{L}$. Equilibrium requires a given level of $\left(c_{s} u_{s}+c_{L} u_{L}\right)$ in order to restrain wage pressure. We now through ALMP improve $c_{L}$, while $c_{s}$ remains unchanged. What happens? $\mathrm{u}_{\mathrm{L}}$ falls and $\mathrm{u}_{\mathrm{s}}$ remains unchanged. Why?

The stock of short-term unemployed depends on the total inflow into unemployment $(\mathrm{S})$ and on the exit rate from short-term unemployment. This latter is equal to $\mathrm{c}_{\mathrm{s}}$ times the exit rate for a person with effectiveness equal to unity, i.e., it equals $\mathrm{c}_{\mathrm{s}} \mathrm{S} / \mathrm{cu} \mathrm{L}$, where $\mathrm{L}$ is labour force. But cu is given. Thus if $\mathrm{S} / \mathrm{L}$ and $\mathrm{c}_{\mathrm{s}}$ remain unchanged, so 
does the exit rate from short-term unemployment and so does the stock of short-term unemployed.

The short-term unemployed get the same number of jobs per period because the long-term unemployed also get the same number of jobs per period. The only thing that has changed is that the stock of long-term unemployed has fallen since the exit rate from long-term unemployment has risen. Thus the long-term unemployed do not take jobs from the short-term unemployed.

There is no job-fund. Employment expands as the effective supply of labour expands. This should be obvious to anyone who contemplates the employment miracle which occurred when the Pilgrim Fathers landed at Cape Cod and found a sudden increase in the demand for labour on those inhospitable shores. But, as expressed so far, it is a medium term argument. In the short-run there may be some constraints on the demand side. For example, if nominal demand is fixed, an increase in the effective supply of labour will generate some new jobs, due to lower inflation, but the increase in jobs will be less than the increase in labour supply. If, however, the government has an inflation target, then even in the short-run employment will increase in line with the effective supply of labour.

This result provides important insights but may need modifying to suit the details of particular schemes. In any case it says nothing about the effectiveness of particular schemes. This depends on how well they do indeed improve the effectiveness of the individuals who are exposed to them.

Clearly schemes are more effective when they are not optional (see above) but then they are also more difficult to study - since there is no control group. Thus most studies of ALMP relate to optional schemes and compare people who were and were not exposed to such schemes. The micro-economic studies have been well summarised in OECD (1993) and Fay (1995). The general findings are (i) a good return to assistance with job-finding, (ii) a goodish return to subsidised self-employment, (iii) some return to targeted recruitment subsidies, (iv) a weaker return to public sector job creation and (v) an often weak 
return to the training of unemployed people. In most cases heavy deadweight is the main factor reducing the return.

Our conclusion is that major expansions of ALMP can only be justified where the aim is to achieve universal coverage of some group (e.g., the long-term unemployed). This will greatly reduce deadweight, since in any disadvantaged group the overall outflow rates are generally low. It is also the only way to make any large dent in unemployment.

Going further, what is needed is in fact a change of regime. When people enter unemployment they need to understand that there will be no possibility of indefinite life on benefits. Instead it should be made clear that, after a period of say one year, public support will be provided only through participation on a programme. But access to the programme is guaranteed. This will have the twin effect of (a) helping those who really need help and (b) driving off the public purse those who only want help in the form of cash.

This is the Swedish model, which played a central role in holding down Swedish unemployment to around 2\% until the end of the 1980s. ${ }^{4}$ The model has of course come under heavy pressure recently due to bad macroeconomic management: over-expansionary policy in the late 1980s followed by over-contraction. The Swedes have been right to continue with ALMP, since institutional/cultural arrangements of this kind cannot easily be re-established once they have been abandoned (Layard, 1995). But the experience makes it clear that ALMP is not primarily a counter-cyclical device - it needs to be a permanent feature of the economic and social system. ${ }^{5}$

\section{WAGE BARGAINING}

The next key factor affecting equilibrium unemployment is the system of wage determination. In systems where wages are settled in a decentralised way (either by employers' fiat or by bargaining) there is always a problem of leapfrogging. Even in the absence of bargaining, some employers may have an incentive to pay an "efficiency" wage 
above the supply price of labour, in order to motivate and retain staff. Indeed, unless unemployment is high enough, they will generally try to pay more than the going wage paid by other employers. Unions will also seek to raise their pay above that of other unions.

This problem of leapfrogging can be reduced when wages are centrally coordinated (namely by centralised positions adopted by the unions and the employers). A simple illustration will suffice, where unions can freely choose their pay so as to maximise the expected income of their members. If the choice is decentralised, the union chooses the firm-level wage $\left(\mathrm{W}_{\mathrm{i}}\right)$ to maximise a function like $\left(\mathrm{W}_{\mathrm{i}}-\mathrm{A}\right) \mathrm{N}_{\mathrm{i}}$ where $\mathrm{N}_{\mathrm{i}}$ is firm-level employment, and $\mathrm{A}$ is expected income outside the firm. A is then given by $(1-u) W^{e}+u B$, where $W^{e}$ is the expected outside wage and $\mathrm{B}$ benefits. (The price level is taken as exogenous.) This leads to a wage given by

$$
\frac{W_{i} \& A}{W_{i}} \cdot\left(\frac{\mathrm{MN}_{i}}{\mathrm{M} W_{i}} \frac{W_{i}}{N_{i}}\right)^{\& 1}
$$

So, for equilibrium $\left(\mathrm{W}_{\mathrm{i}}\right.$ equal to $\left.\mathrm{W}^{\mathrm{e}}\right)$, unemployment is given by

$$
u^{\prime}\left(\frac{\mathrm{MN}_{i}}{\mathrm{M} W_{i}} \frac{W_{i}}{N_{i}}\right)^{\& 1}\left(1 \& \frac{B}{W}\right)^{\& 1}
$$

By contrast a centralised union would be setting the wage for everybody and would choose it to maximise NW, recognising that workers disemployed by the wage settlement would have no alternative income opportunity (so that $\mathrm{A}=0$ ), unemployment benefits simply being a transfer from employed to unemployed union members. Unless an increase in employment required a more than proportionate fall in the real wage, the union would choose a wage consistent with full employment. A similar result can be obtained in a wage bargaining 
model. If by contrast employers set efficiency wages, there are also advantages from coordination to reduce leap-frogging, though employers would collectively choose non-zero unemployment as a worker-discipline device.

All this is on the assumption of homogenous labour. If labour is heterogenous, the arguments for decentralisation become more powerful. Under coordinated bargaining it is quite difficult to achieve the shifts in relative wages that may be required in response to differential shifts of relative demands and supplies. Thus coordinated bargaining reduces unemployment by cutting out leapfrogging, but increases it by worsening structural imbalances. The overall outcome is an empirical issue.

The issue appears to be quite clearly resolved in Table 2 . Coordination has a powerful influence in reducing unemployment. An uncoordinated economy will have, other things equal, an unemployment rate more than twice as high as an economy with highly coordinated wage-setting arrangements. Our results suggest, however, that a fully co-ordinated economy with a high degree of union coverage will have approximately the same unemployment rate as an economy with low union coverage and no coordination.

In this context we should perhaps refer to the view of Calmfors and Driffill (1988) that, while full centralisation has advantages, coordination at the industry level gives the worst of all worlds (due to the low demand elasticity for labour in one industry). The implication is that if full centralisation is too difficult, one should go for full decentralisation. We believe this argument is misleading. On the empirical level the finding is not robust (Soskice, 1990). Moreover it ignores the obvious point that, when comparing countries, it is not only the degree of centralisation which rises but the degree of union coverage. The USA does not have decentralised bargaining; it has hardly any unions. Other things equal, higher coverage is bad for employment but this effect can be offset by sufficient coordination. This is precisely what our equation shows. 
With regard to the impact of relative wage flexibility, we tried introducing the degree of wage dispersion as a further independent variable in the Table 3 regressions. It turned out insignificant in relation to total unemployment $(\mathrm{t}=0.6)$ and long-term unemployment $(t=-0.9)$, but to have a significant positive effect $(t=4.2)$ in increasing short-term unemployment. These results suggest the complexity of the issues surrounding wage flexibility.

The truth is that coordination is a very subtle affair. ${ }^{6}$ But the more there is, it appears, the better. Equally the task of achieving it appears to have become more difficult, possibly reflecting the greater exposure to international competition in both product and factor markets in recent years.

\section{SKILLS IMBALANCE ${ }^{7}$}

One possible reason why unemployment is higher than in the 1970s is the steady fall in the demand for unskilled workers. If this is not matched by an equal fall in supply, this can certainly cause an increase in unemployment.

To see this we can (for simplicity) divide the labour force into two categories, skilled and unskilled denoted 1 and 2 respectively. We shall assume that output is produced by a Cobb-Douglas production function

$$
Y^{\prime} A N_{1}^{\mathrm{a}_{1}} N_{2}^{\mathrm{a}_{2}} K^{\mathrm{a}_{3}} \quad\left(\mathrm{a}_{1} \% \mathrm{o}_{2} \%_{3}^{\prime} 1\right)
$$

Thus the demand for labour of type $\mathrm{i}$ is given $\mathrm{by}^{8}$

$$
\ln W_{i} \ddot{i} \operatorname{loga}{ }_{i} \% \operatorname{og}(Y / L) \& \log l_{i} \%{ }_{i}
$$

where $\mathrm{W}$ is the cost per worker, $\mathrm{L}$ total labour force and $\mathrm{l}_{\mathrm{i}}=\mathrm{L}_{\mathrm{i}} / \mathrm{L}$. It follows that, if the unemployment rate of a group is to remain constant 
when $a_{i}$ rises or falls, wages must adjust in line. Equally, when the labour force composition changes, wages must also adjust.

The problem is that wages do not normally adjust as they 'should'. Usually it takes extra unemployment to get wages down. There is much evidence to support the following wage equation

$$
\ln W_{i}^{\prime} \& ? \log u_{i} \%{ }_{i} \% \operatorname{og}(Y / L)
$$

where $\mathrm{Z}_{\mathrm{i}}$ measures a return of wage pressure effects. From (1) and (2) we can see that the unemployment of a group is determined by

$$
u_{i}{ }^{\circ} / \log u_{i}{ }^{\prime} \log l_{i} \& \operatorname{loga}{ }_{i} \%{ }_{i}
$$

If the relative demand for a group $\left(a_{i}\right)$ falls faster than the relative supply of people in that group $\left(l_{\mathrm{i}}\right)$, then $\left(\log l_{\mathrm{i}}-\log \mathrm{a}_{\mathrm{i}}\right)$ falls, and the unemployment rate in that group rises. There is thus a ceaseless race between shifts in demand and shifts in supply.

The change in unemployment of group $i$ is

$$
d u_{i}^{\prime} \mathrm{f}_{i}\left(d \log l_{i} \& d \operatorname{loga} \mathrm{a}_{i}\right)
$$

where $\mathrm{f}_{\mathrm{i}}=\mathrm{u}_{\mathrm{i}} /\left(\mathrm{u}_{\mathrm{i}}+?\right)$. We can interpret this in terms of Figure 2 . The demand for type i labour (relative to its supply) shifts to the left by the same amount if the labour supply $\left(l_{i}\right)$ increases by $1 \%$ or the labour demand $\left(\mathrm{a}_{\mathrm{i}}\right)$ falls by $1 \%$. Both of the shifts in supply and demand have the same effect. The effect on unemployment is greater the more rigid are wages. The lower is ? the more rigid are wages and the greater the rise in unemployment. Moreover the absolute rise in unemployment is greater the higher the existing level of unemployment $\left(u_{i}\right)$ - due to the curved nature of the wage function. 
In modern societies a race is in progress between the increase in the demand for skilled labour (measured by $a_{1}$ ) and the supply of skilled labour (measured by $l_{1}$ ). If the supply of skill fails to increase as fast as the demand, total unemployment will rise. To see this, note that the total change in unemployment is

$$
\begin{gathered}
\left.d u^{\prime} d\left(u_{1} l_{1} \% l_{2} l_{2}\right)^{\prime} u_{1} d l_{1} \& u_{2} d l_{1} \%_{1} d u_{1} \% 1 \& d_{1}\right) d u_{2} \\
\left.{ }^{\prime} \&\left(u_{2} \& u_{1}\right) d l_{1} \&\left(\mathrm{f}_{2} \& f_{1}\right) d l_{1} \% ?_{2} \& ?_{1}\right) d \mathrm{a}_{1}
\end{gathered}
$$

where $?_{\mathrm{i}}=\mathrm{f}_{\mathrm{i}} l_{\mathrm{i}} / \mathrm{a}_{\mathrm{i}}$.

The first of these terms is a pure composition effect - if the labour force becomes more concentrated in low-unemployment groups, unemployment will tend to fall. The second term reflects the problems which stem from wage rigidity. Since log wages depend on $\underline{\log }$ unemployment, one extra point of unemployment reduces wages less for a group whose unemployment is high. Thus switching labour into the skilled group reduces overall unemployment - the downwards force on skilled wages outweighs the upwards force on unskilled wages ( $\mathrm{f}_{2^{-}}$ $\mathrm{f}_{1}>0$ ). The third term shows the effect of technical progress raising the relative demand for skilled labour. Since $l_{2} / a_{2}>1$ and $1_{1} / a_{1}<1$, a rise in the demand for skilled labour $\left(\mathrm{a}_{1}\right)$ raises overall unemployment, by raising the demand for labour where the wage pressure responds sharply to extra demand and reducing demand where wages are unresponsive to demand.

\section{Empirical work}

Empirical work using this kind of approach is still at a preliminary stage. However Nickell and Bell (1995a and b) give results using a similar model, with a more general CES production function. They tentatively estimated that on average one fifth of the rise in unemployment from the late 70s to the late 80s in Germany, Holland, Spain, UK and Canada was due to structural shifts of demand relative to supply. Nickell (1995b) gives similar results. 


\section{EMPLOYMENT PROTECTION}

It is widely believed that labour market flexibility is good for the macroeconomy and that employment protection legislation is an impediment to such flexibility. So it is argued that freedom of action for employers to dismiss workers on economic grounds is necessary for a smoothly functioning economy, though it is of course desirable to protect employees from arbitrary, unfair or discriminating dismissals. However, it may be tricky in practice to protect employees from arbitrary dismissal while simultaneously allowing freedom of action for employers to dismiss on economic grounds. Thus it may be felt necessary by benevolent legislators to circumscribe this freedom of action. ${ }^{9}$ The macroeconomic consequences of this are, however, of major importance - both on the process of short-run adjustment and on the long-run equilibrium level of unemployment.

\section{Theoretical background}

Employment protection has a potential impact at a number of different points in the operation of the labour market. It obviously impedes employment adjustment by reducing both flows from employment, because of the legal hurdles, and flows into employment by making employers more cautious about hiring. It may also influence wage determination, for example by raising the power of insiders or by lengthening unemployment duration. Finally, because of the excessive caution of employers, it may impede the absorption of new entrants into the labour market thereby reducing participation rates and raising relative youth unemployment rates.

Consider the following model, where we ignore nominal inertia (wage/price stickiness), labour force growth and trend productivity effects. Wage setting is given by

$$
\log W^{\prime} \& ?_{1} u \& ?_{11} ? u \%_{w}
$$


where $\mathrm{z}_{\mathrm{w}}$ are wage pressure shocks. The demand for labour is given by

$$
\left.n^{\prime} ? n_{\& 1} \&(1 \& ?) \beta_{1} \log W \% 1 \& ?\right) z_{n}
$$

$\mathrm{n}=\log$ employment, $\mathrm{Z}_{\mathrm{n}}=$ labour demand shifts (e.g., productivity shocks) and $\beta_{1}$ is the long-run labour demand elasticity. If we suppose the labour force to be fixed and normalised to unity, (8) can be written as

$$
u^{\prime} ? u_{\& \mathrm{l}} \%(1 \& ?) \beta_{1} \log W \&(1 \& ?) z_{n}
$$

Then, eliminating real wages from (7) and (9), we obtain

$$
u^{\prime} \mathrm{a}_{11} u_{\& 1} \%\left(1 \& \mathrm{a}_{11}\right) u^{(}
$$

where $\mathrm{u}^{*}$ is the equilibrium unemployment rate, given by

$$
u^{(1} \frac{\beta_{1} z_{w} \&_{n}}{1 \beta_{1} ?_{1}},
$$

and the speed of adjustment, $1-\mathrm{a}_{11}$, is given by

$$
1 \& a_{11}{ }^{\prime} \frac{\beta_{1} ?_{1} \%}{\beta_{1} ?_{1} \% \beta_{1} ?_{11} \%(\& 1 \&)^{\& 1}} .
$$

From this analysis, we see that there are two important questions. First, how might employment protection influence the speed of adjustment, 1-a $\mathrm{a}_{11}$ ? Second, how might employment protection affect the equilibrium unemployment rate, $u^{*}$ ? The first of these is 
straightforward. We would expect employment protection to raise employment adjustment costs and this would increase?. Furthermore, employment protection may tend to increase long-term unemployment by reducing the rate of flow from unemployment to employment, as employers become more cautious about hiring. This will typically generate hysteresis effects in wage determination and thereby raise $?_{11}$. Increases in both ? and $?_{11}$ will tend to reduce the overall speed of adjustment, $1-\mathrm{a}_{11}$.

Turning to the second question, namely the impact on equilibrium unemployment, it is important to recognise that, just because employment protection may tend to lengthen the duration of unemployment spells, this does not mean that it will necessarily raise equilibrium unemployment, $\mathrm{u}^{*}$. For offsetting the duration effect is the reduction in flows. The flow into unemployment is obviously reduced by regulations designed to restrict dismissals. Since the unemployment rate is the product of the inflow rate and the mean duration, the overall effect of employment protection on $\mathrm{u}^{*}$ is indeterminate.

Looking at the formula for $\mathrm{u}^{*}$ in (11), there are a number of possibilities. First, employment protection may influence wage pressure, $\mathrm{z}_{\mathrm{w}}$, directly, for example, by raising the power of insiders. Second, employment protection can raise the impact of unemployment on wages, ? ${ }_{1}$, by making the threat of unemployment more unpleasant (longer duration, harder to find alternative employment). On the other hand, of course, since employees are protected against dismissal to some extent, the threat of unemployment is less germane and this will reduce $?_{1}$. So the overall effect on $\mathrm{u}^{*}$ is ambiguous.

Finally, we have not modelled participation in this exercise but we should consider the implications of employment protection for employment rates as well as unemployment rates when we come to our empirical investigation.

\section{Evidence on unemployment dynamics}


Our purpose in this section is to explore the evidence on the relationship between employment protection, employment adjustment and both the dynamics of labour demand (?) and the extent of hysteresis in wage determination $\left(?_{11}\right){ }^{10}$

We first investigate the relationship between some empirical measures of ?, a measure of the rate of turnover of employees within companies (the percentage of employees with job tenures less than 2 years, PL2) and the OECD composite ranking of the tightness of employment protection (EP). The data are reported in Table 4. The first point to note is the very strong correlation between EP and PL2, the correlation coefficient between the two variables being 0.9 . So the variation in the rate of turnover (as captured by the proportion of employees with less than two years tenure) is explained almost entirely by the strictness of the employment protection laws. The relationship between PL2 and our various measures of ? is set out in Table 5. In two out of the three cases, we see that PL2 is significantly related to the aggregate measure of labour demand sluggishness (?). Overall, therefore, there is some evidence in favour of the hypothesis that the speed of adjustment in labour demand is negatively related to the strictness of employment protection legislation.

Turning next to wage determination, we are concerned here with the relationship between the degrees of hysteresis $\left(?_{11}\right)$ and employment protection, operating via long-term unemployment. The impact of long-term unemployment on the extent of hysteresis is confirmed explicitly in Layard et al. (1991), Chapter 9, Table 9 and implicitly in OECD (1993, Chapter 3). ${ }^{11}$ So we can simply focus on the impact of employment protection on long-term unemployment, in particular on the proportion of the unemployed who have a duration of more than one year. As well as employment protection, we should also expect the long-term proportion to be influenced by the duration of benefit availability (BD) and by expenditure on active labour market policies (ALMP), many of which are designed to prevent the build-up of long-term unemployment. In Table 4 we provide two measures of long-term unemployment. The first is simply the 1985-93 average 
proportion of unemployed with durations exceeding one year. The second attempts to standardise this proportion, when possible, by measuring it for each country when unemployment lies between 5 and 7\%. The idea here is to focus on the extent of long-term unemployment at given levels of aggregate unemployment. Because the long-term proportion tends to be an increasing function of the overall unemployment rate in the long-run, anything which explains unemployment in general will tend to be correlated with the long-term proportion in a cross-section. The standardised measure will eliminate this problem.

The relevant regressions explaining the two measures of the longterm proportion are:

LTU (standardised) $\quad=21.5+0.24 \mathrm{BD}-0.51 \mathrm{ALMP} 87+0.55 \mathrm{EP}+13.8 \mathrm{IT}$

$$
\mathrm{N}=19, \mathrm{R}^{2}=0.55
$$


(IT is a dummy for Italy, which is included because although Italy has only a short benefit duration, the level of benefit is negligible so its duration is irrelevant.) The overall picture is that there is some evidence that stricter employment protection legislation raises longterm unemployment and thus enhances hysteresis in wage-setting. When added to the results on labour demand, we feel that we have some fairly strong and coherent evidence that the strictness of employment protection legislation does influence labour market dynamics by raising unemployment persistence. Whether or not it influences the equilibrium level of unemployment is the issue we consider next.

\section{Evidence on equilibrium unemployment}

As we noted earlier, employment protection can influence equilibrium unemployment by directly influencing wage pressure and/or by affecting the impact of unemployment on wages $\left(?_{1}\right)$. This latter parameter is crucial in translating wage pressure into unemployment (see equation 11).

We begin by looking at the effect of employment protection on $?_{1}$ and then move onto consider its overall impact on average unemployment. As we argue in Layard et al. (1991), there are a number of other possible factors which can influence ${ }_{1}$. These include the structure of the benefit system (replacement rates and benefit duration), and the extent of union and employer coordination in wage bargaining. In Table 4 , we present estimates of $?_{1}$ from Layard et al. (Chapter 9, Table 7). The relevant regression to explain ${ }_{1}$ is 
$?_{1}=11.9-0.078 \mathrm{RR}-2.12 \mathrm{BD}+1.32(\mathrm{UNCD}+\mathrm{EMCD})+0.23 \mathrm{EP}$
$(0.9)$
(4.8)
(2.3)
$(1.7)$

$\mathrm{N}=19, \mathrm{R}^{2}=0.71$

This indicates that if employment protection legislation is very strict, this tends to be associated with high values of ? ${ }_{1}$. Of course, EP is not significant at conventional levels but it is most unlikely that there is, in reality, a strong effect in the opposite direction. So, from this channel the data indicate, if anything, employment protection reduces unemployment. But, since we know that employment protection can also increase wage pressure, we must also investigate its total impact on unemployment.

This was done in Table 3. As this showed, there is some weak evidence that employment protection tends overall to increase employment. But the t-statistics are never very significant. We ran a large number of further variations using alternative measures of union density and union coverage and also different measures of employment protection. In some eighteen regressions, we were able to obtain only two significant negative coefficients on EP. So there is no strong evidence that employment protection affects equilibrium unemployment. This is, of course, consistent with the fact that while we have good reason to expect employment protection legislation to reduce flows both into and out of unemployment, we have no strong reasons for believing either effect to dominate.

\section{Conclusions}

We would expect employment protection legislation to slow down the speed with which the labour market adjusts to shocks but to have only a minor impact on the long-run equilibrium. It may however affect the position of those entering or re-entering the labour market because of the effective restrictions on hiring. In practice, there is considerable evidence that employment protection reduces adjustment 
speeds in the labour market. But it is hard to find any significant effects on equilibrium unemployment rates.

\section{TAXES ON EMPLOYMENT}

Lowering payroll taxes is a perennial suggestion by those concerned to reduce unemployment. Thus the OECD Jobs Study (1994) recommends that we should "Reduce non-wage labour costs, especially in Europe, by reducing taxes on labour...." (p.46). The European Commission's White Paper on Employment proposes a reduction in payroll taxes in conjunction with an increase in taxes on energy. Another straightforward policy would be to lower payroll taxes and make up the shortfall by raising consumption taxes. Phelps (1994) argues that "such a substitution of tax instruments would achieve a major gain in employment and some gain in the general level of real wage rates as well" (p.28). Presumably, such a switch would work equally as well in a non-European country, such as the United States, where the sum of payroll and income taxes is substantial.

The general argument for this switch goes as follows. ${ }^{12}$ Payroll taxes apply only to labour income; consumption taxes apply to all income (which is spent). So a switch from the former to the latter raises the reward for working relative to not working and thereby reduces unemployment. More formally, we may write total real income in work net of taxes, $\mathrm{Y}$, as

$$
Y^{\prime} \frac{W\left(1 \& t_{1}\right)\left(1 \& t_{2}\right)}{P\left(1 \% \%_{3}\right)} \frac{Y_{n}\left(1 \& t_{2}\right)}{P\left(1 \% \psi_{3}\right)}
$$

where $\mathrm{W}=$ labour costs, $\mathrm{t}_{1}=$ payroll tax rate, $\mathrm{t}_{2}=$ income tax rate, $\mathrm{P}=$ output

price at factor cost, $t_{3}=$ consumption tax rate, $Y_{n}=$ non-labour income. This may be rewritten as 


$$
Y^{\prime} \frac{? W}{P}\left(1 \% \frac{y_{n}}{\left(1 \& t_{1}\right)}\right)
$$

where ?=(1-t $\left.t_{1}\right)\left(1-t_{2}\right) /\left(1+t_{3}\right) \ddot{I}\left(1-t_{1}-t_{2}-t_{3}\right)$, the tax wedge, $y_{n}=Y_{n} / W$, the ratio of non-labour income to labour costs. Consider now the real income when unemployed, $\mathrm{Y}^{\mathrm{u}}$. This may be written as

$$
\begin{aligned}
& Y^{u \prime} \frac{B\left(1 \& t_{2}\right)}{P\left(1 \% \sigma_{3}\right)} \frac{Y_{n}\left(1 \& t_{2}\right)}{P\left(1 \% \sigma_{3}\right)} \\
& \text {, } \frac{? W}{P}\left(b \% \frac{y_{n}}{1 \& t_{1}}\right)
\end{aligned}
$$

where $b=B / W\left(1-t_{1}\right)=$ unemployment benefit/wage ratio. The definition of $\mathrm{Y}^{\mathrm{u}}$ assumes that benefits are subject to income tax.

In most theories of wage determination, the wage cost which is set depends on $Y / Y^{u}$ which is increasing in $b, y_{n}$ and $t_{1}$. Increases in $b, y_{n}$ and $t_{1}$ will, therefore, automatically raise equilibrium unemployment. So a reduction in $t_{1}$ and an equal increase in $t_{3}$ will leave the tax wedge, ?, unchanged but will lower equilibrium unemployment so long as $\mathrm{y}_{\mathrm{n}}$ is not zero. ${ }^{13}$ How big is this effect? The crucial factor is the extent of non-labour income which is not subject to payroll tax. It is arguable that, for the typical person at risk of unemployment, this nonlabour income is extremely small. For example, in 1987/8, only $7 \%$ of unemployment entrants in Britain had savings of more than $£ 3 \mathrm{~K}$, a sum which would produce an annual interest income of around $10 \%$ of unemployment benefit. ${ }^{14}$ So it may be that this tax switching effect is simply too small to have any noticeable effect.

A more fundamental question is whether any of the taxes (payroll, income or consumption) have an impact on labour costs in the long-run, or whether they are all eventually shifted onto labour. An 
obvious first approach to this issue is to see whether countries with high taxes have higher labour costs than those with low taxes. We must obviously correct for productivity which suggests that we correlate $\frac{W}{P} / \frac{Y}{N}$ with tax rates across countries $(\mathrm{W}=$ labour costs, $\mathrm{P}=\mathrm{GDP}$ deflator, $\mathrm{Y}=\mathrm{GDP}, \mathrm{N}=\mathrm{employment}$ ). But this procedure is open to objection. Real labour costs normalised on productivity is precisely equivalent to WN/PY, the share of labour. In a Cobb-Douglas world, for example, an increase in taxes might lead to a rise in W/P and a fall in $\mathrm{N}$, with the share of labour unchanged. The proposed correlation will then understate the true impact of taxes because of the fall in $\mathrm{N}$ when labour costs rise. This suggests that we normalise real labour costs on $\mathrm{Y} / \mathrm{L}$ where $\mathrm{L}$ is the labour force.

Taking average values over the period 1980-90 for thirteen OECD countries ${ }^{15}$ we obtain

$$
\begin{gathered}
\mathrm{WL} / \mathrm{PY}=7.06+0.017 \mathrm{t}_{1}+0.033 \mathrm{t}_{2}-0.12 \mathrm{t}_{3} \\
(0.6) \quad(0.5) \\
(0.9)
\end{gathered}
$$

where $t_{1}$ is the payroll tax rate, $t_{2}$ is the income tax rate, $t_{3}$ is the consumption tax rate. Basically there is no relationship between tax rates and labour costs, indicating complete shifting onto labour. A similar result due to James Symons and Donald Robertson and based on changes is reported in OECD (1990), Annex 6A. Using changes between 1974 and 1986 across 16 OECD countries, ${ }^{16}$ they obtain

$$
\begin{gathered}
\log \mathrm{W} / \mathrm{P}=-0.05+0.09 ? \mathrm{t}_{1}+0.33 ? \mathrm{t}_{2}+0.68 ? \mathrm{t}_{3}+0.97 ? \log \mathrm{PROD} \\
(0.3) \quad(0.6)
\end{gathered}
$$

$\left(\mathrm{R}^{2}=0.80, \mathrm{~N}=16, \mathrm{t}\right.$ ratios in brackets; $\mathrm{PROD}$ is labour productivity) 
Here again we see no significant effects of tax changes on real labour costs although the numbers suggest that consumption taxes have the biggest impact.

While these cross-section regressions are useful for looking at long-run tax shifting, only time- series analysis can shed light on the dynamics. First we report some further results in the same Annex due to Symons and Robertson, which are the average coefficients and $t$ ratios emerging from individual time-series regressions for 16 OECD countries. Thus we have

$\log (\mathrm{W} / \mathrm{P})_{\mathrm{t}}=$

const. $+0.84 \log (\mathrm{W} / \mathrm{P})_{\mathrm{t}-1}+0.12 \log (\mathrm{K} / \mathrm{L})_{\mathrm{t}}+0.46 ?\left(\mathrm{t}_{1}+\mathrm{t}_{2}+\mathrm{t}_{3}\right)+0.07 \mathrm{t}_{1}-$ $0.07 \mathrm{t}_{2}+0.26 \mathrm{t}_{3}$

(average $t$ ratios in brackets)

These results suggest there is no systematic long-run impact of taxes on labour costs but that the short-run effects are substantial. A one percentage point increase in the tax wedge (from whatever source) leads to a short-run increase in labour costs of around $1 / 2 \%$ which takes a long time to fade away. So even after four years, labour costs are still $1 / 4 \%$ higher. Such effects will lead to significant and persistent temporary increases in unemployment, particularly in the light of the fact that tax wedges have risen by 10 to 20 percentage points in the last 30 years in most OECD countries. In the long-run, however, these unemployment effects will disappear.

These significant and long-lasting temporary tax effects imply that, when looking at individual country data, it is very difficult to discriminate between the short and long-run impacts of the individual taxes. There is simply not enough information. Consequently, the impression given by the collection of individual country time series 
studies of wage determination is that the estimated tax effects are all over the place.

It is not worth repeating the summaries in Layard et al. (1991), p.210 and OECD (1994), p.247 but we may consider one recent example, namely the work of Tyrväinen reported in OECD (1994). ${ }^{17}$ This work focuses on the long-run effects of taxes by using the Johansen method to estimate long-run cointegrating relationships between labour costs, taxes and other relevant variables. The long-run tax effects he obtains are given in Table 6 . The first point that stands out is how big the tax effects are. Whereas our previous evidence indicated zero long-run tax effects, here we have a substantial long-run impact of taxes. Second, in all bar two of the countries, the tax effects are uniform across all taxes. Indeed, in no country is there any advantage in switching from payroll taxes to consumption taxes. ${ }^{18}$

We have investigated these matters further in the context of our pooled regression equation of Table 3 . The payroll tax rate, as an additional explanatory variable turns out to be insignificant (with a tstatistic of 0.4 ) though the total tax burden as \% of GDP comes in with a small significant positive coefficient (though no effect on long-term unemployment). These results require further investigation.

On balance, we may perhaps conclude that taxes may have an adverse effect on unemployment in the long run, but any such effect is smallish, and that it relates to the burden of taxation in total and not to payroll taxes in particular. ${ }^{19}$

\section{WORK-SHARING AND EARLY RETIREMENT}

Two final much-canvassed solutions to unemployment are reduced hours of work and early retirement. Advocates of these measures often seem to believe that there is some exogenous limit to the amount of work to be done. But history shows that, for a given institutional structure, the amount of work tends to adjust in line with the available supply of labour - leaving the equilibrium rate of 
unemployment unchanged. We can begin with some theoretical remarks, before supporting them with evidence.

\section{Theoretical issues}

We shall first examine the underlying theory in a long-term context, using for illustration a simple efficiency wage model. Efficiency per worker hour is e, which depends on hourly wages $\left(\mathrm{W}_{\mathrm{i}}\right)$ relative to the expected wage $(\hat{\mathrm{W}})$ and on the unemployment rate: $\mathrm{e}_{\mathrm{i}}=\mathrm{e}\left(\mathrm{W}_{\mathrm{i}} / \hat{\mathrm{w}}, \mathrm{u}\right)$. Output is given by $f(\mathrm{eHN})$ where $\mathrm{H}$ is hours per worker, which can be varied exogenously. Then the profits of the representative firm are

$$
\mathrm{p}_{i}^{\prime} f\left(e_{i} H N_{i}\right) \& \frac{W_{i}}{e_{i}} e_{i} H N_{i} \quad\left(f^{\prime}>0, f^{\prime)}<0\right)
$$

The problem is recursive and the firm can first choose $\mathrm{W}_{\mathrm{i}}$ to minimise $\mathrm{W}_{\mathrm{i}} / \mathrm{e}_{\mathrm{i}}$. The optimum wage is then given by

$$
e_{1}\left(\frac{W_{i}}{\hat{W}}, u\right) \cdot e\left(\frac{W_{i}}{\hat{W}}, u\right)
$$

Hence in general equilibrium (with $\mathrm{W}_{\mathrm{i}}=\hat{\mathrm{W}}$ ) unemployment is determined by

$$
e_{1}(1, u)^{\prime} e(1, u)
$$

This holds irrespective of hours.

This result arises because the change in hours affects both those making the wage comparison and the reference group with which the comparison is being made. In the long run both groups must be paid the same. However in the short run things could be different, especially if people are comparing their wage with what they think they "ought to" be paid - as in many models of real wage resistance. The 
problem here is that people's ideas of what they should be paid adjust only gradually to the reality of what they are paid. Thus

$$
? \log \hat{W}^{\prime} ?\left(\log W_{\& 1} \& \log \hat{W}_{\& 1}\right)
$$

Suppose there is now a downwards productivity shock. Sluggish adjustment of the reference wage will for a time prevent actual wages falling as much as is needed to preserve employment. In this case reduced hours can be an appropriate adjustment to temporary shocks. Indeed in general there can be no objection to allowing hours to act as shock-absorbers, as in Japan. But this is quite different from saying that lower hours will secure permanently higher employment. They will not, and they will also reduce the national output.

Similar arguments apply to the use of early retirement. Since labour market equilibrium requires a given unemployment rate, reductions in labour supply will simply reduce equilibrium employment. Employment will of course take a while to adjust down, and, until it does, there will be extra inflationary pressure in the economy - which eventually leads to the necessary fall in real aggregate demand (assuming nominal demand follows a steady path). However again a negative productivity shock together with real wage resistance will lead to less unemployment if the labour force is temporarily reduced.

\section{Empirical analysis}

It is fairly simple to check on these basic lines of reasoning. We ran the following wage equation for each of our usual 19 OECD countries for the years 1952 to 1990 :

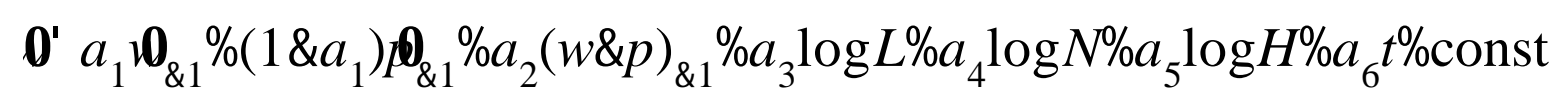


where $\mathrm{w}$ is log hourly earnings in manufacturing, $\mathrm{p}$ is log consumption deflator, $\mathrm{L}$ is labour force, $\mathrm{N}$ employment, $\mathrm{H}$ is average weekly hours in manufacturing and $t$ is time. We then computed the average value of each coefficient (averaged across all countries) and its average tstatistic.

If our reasoning has been correct we would expect

(i) $\log \mathrm{H}$ to have no significant effect, and

(ii) $\mathrm{a}_{3}$ to be insignificantly different from $\left(-\mathrm{a}_{4}\right)$, indicating that it is the unemployment rate which affects wage pressure and the size of the labour force exerts no independent influence.

Both expectations were born out. The equation looked as follows, with average coefficients and average t-statistics:
$\mathrm{w}^{0}=0.37 \mathrm{w}_{-1}^{0}+0.63 \mathrm{p}_{-1}^{0}-0.12(\mathrm{w}-\mathrm{p})_{-1}-2.10 \log \mathrm{L}+1.82 \log \mathrm{N}-$ $0.16 \log \mathrm{H}+0.008 \mathrm{t}+$ const.

Hours have no significant effect and a cut in the labour force raises wage pressure in a way that can only be offset by an equivalent cut in jobs.

We again examine these effects also in the context of our pooled cross-section regression of Table 3. Average hours worked, as additional explanatory variable, had a small but statistically insignificant $(\mathrm{t}=1.1)$ negative effect on unemployment. A more rapid growth of the labour force was also associated with significantly $(t=2.4)$ lower unemployment, but this result is not very plausible, and may reflect largely the rapid growth of the labour force in the United States.

\section{CONCLUSIONS}

We have found clear evidence that unemployment is strongly affected by how unemployed people are treated and by how wages are 
determined. There are also indications that problems of skill mismatch have exacerbated European unemployment. As regards employment protection, there is no clear evidence of whether it decreases the outflow rate from unemployment by more or less than it decreases the inflow rate. And there appears to be no long-term effect on unemployment rates from employment taxes or from worksharing/early retirement.

Thus it is unhelpful to focus the discussion of unemployment on the concept of flexibility. Clearly lower benefits and less employment protection are examples of more flexibility. But active labour market policy, coordinated wage bargaining, and skill training are not exactly forms of flexibility.

It seems better to focus on the proper role of government in affecting unemployment. Clearly lower benefits of shorter duration would reduce unemployment, but these policies should be accompanied by more (not less) active labour market policy. Similarly governments would be ill-advised to encourage the dismantling of bargaining structures. And they ought certainly to ensure that most youngsters enter adult life with a basic level of competence.

Indeed if Europe's social chapter is to contribute to lower unemployment in Europe it needs to impose two further obligations on governments: a) to prevent entry to long-term unemployment (by replacing long-term benefits by active labour market policy), and b) to prevent young people ceasing their education (full-time or part-time) until they have acquired basic literacy, numeracy and vocational competence. 


\section{ENDNOTES}

1. We are extremely grateful to Tim Hughes and Jan Eeckhout for help with Sections 1 and 7, to Marco Manacorda and Barbara Petrongolo for allowing us to draw on their work in Section 4, to W. Roëger for helpful comments, and to Philomena McNicholas for typing the paper.

2. We also used the less conventional measure of "the change in inflation relative to its initial level" - to allow for the extra difficulty of reducing inflation when it is low. This was only marginally more significant then the conventional measure and barely affected the other coefficients. We also tried including the trade deficit since inflation can always be reduced by a real exchange rate appreciation; but it was insignificant and wrongly signed.

3. We are indebted to our discussant, W. Roëger, for emphasising this point.

4. The other main influence was coordinated wage-bargaining. We reject the view that high employment was based on money illusion and repeated devaluation.

5. Because of cyclical effects on the scale of ALMP it is difficult to study the effect of ALMP on wage pressure (and thus unemployment) from time series data, as has often been tried (Calmfors and Nymoen, 1990; Calmfors and Forslund, 1991). The best evidence must come from cross-sectional comparisons such as our international comparisons in Table 3 or (when available) more microeconomic comparisons of the effects of institutional differences.

6. For a full discussion of the degree of coordination in 12 countries see Soskice (1990). 
7. This draws heavily on the work of our colleagues M. Manacorda and B. Petrongolo (1995).

8. Since $\ln W_{i}{ }^{\prime} \operatorname{loga}{ }_{i} \% \operatorname{og}\left(\frac{Y}{L} \frac{L}{L_{i}} \frac{L_{i}}{N_{i}}\right)$

9. There is also an important productivity argument. It is well known that a participatory environment is good for company productivity (see Nickell, 1995a, Chapter 5) and that, as part of this environment, some degree of job security is required. If the remainder of the economy is governed by very loose employment protection laws, any employer who wishes to introduce some degree of job security for the above reasons may be so beset by adverse selection problems that she is unable to operate a participatory system. This mechanism could easily operate to the detriment of national productivity growth.

10. When analysing labour demand dynamics on the basis of aggregate data, it is necessary to face up to some criticisms of this activity set out by Kramaz (1991), Caballero (1992) and Hamermesh (1992). Thus Hamermesh argues that "one cannot use aggregate dynamics to examine or compare the structures or sizes of adjustment costs" (p.8). Since we intend to do just this, we must examine the arguments closely.

Hamermesh looks at three types of adjustment cost structures, namely fixed costs, linear costs and asymmetric quadratic costs. In each case he concludes that, in aggregate, the adjustment speed is related both to micro adjustments costs and to the cross-section variance of sectoral shocks. When looking across countries there is, therefore, the danger that any correlation between adjustment speeds and adjustment costs is corrupted by our inability to control for the variance of sectoral shocks. It is more or less impossible to obtain comparable measures of the variance of 
sectoral shocks because of the difficulty of obtaining consistent sectoral breakdowns across a large number of countries. However, this corruption will only be serious if the cross-section variance of shocks is strongly correlated with adjustment costs across countries. While we have no evidence on this, there seem to be no strong a priori arguments in favour of such a correlation, in which case the omission of this variable is not a problem. Finally, it is worth remarking that estimated labour market dynamics look very similar at the aggregate and at the firm level. For example, the dynamics of a UK aggregate annual employment equation have the form $\mathrm{n}_{\mathrm{t}}=1.06 \mathrm{n}_{\mathrm{t}-1}-0.36 \mathrm{n}_{\mathrm{t}-2}+$ etc., whereas a similar annual equation based on UK company data has dynamics $\mathrm{n}_{\mathrm{t}}=0.83 \mathrm{n}_{\mathrm{t}-\mathrm{1}}-0.14 \mathrm{n}_{\mathrm{t}-2}+$ etc. ,

(see Layard et al. 1991, Chapter 9, Table 15, and Nickell and Wadhwani, 1991, Table III). Both exhibit a considerable degree of persistence, with shocks dying away at a very similar rate.

11. The results in OECD (1993), Table 3.5 indicate a strong positive relationship between wages and long-term unemployment at given unemployment rates. Since long-term unemployment is negatively related to unemployment changes in the short-run, this asserts a positive relationship between long-term unemployment and hysteresis effects (negative effects of unemployment changes on wages).

12. This is the non-labour income argument. Hoon and Phelps (1995) also provide a real interest rate argument which we do not consider here.

13. The effect will be enhanced if $B$ is exogenous, rather than B/W(1$\mathrm{t}_{1}$ ). Typically, however, most countries (although not Britain) set the replacement ratio rather than the level of benefit.

14. See Layard et al. (1991), Table A6.

15. These are Australia, Belgium, Canada, Denmark, France, 
Germany, Italy, Japan, Netherlands, Spain, Sweden, UK, US.

16. These are those recorded in endnote 15 plus Austria, Finland, Ireland, Norway and Switzerland minus Denmark and Spain.

17. See OECD (1994), p.246.

18. So long as the tax base for these is the same. If, of course, it happens that the consumption tax base is larger, then a lower consumption tax rate would raise the same revenue and have a lesser impact on labour costs.

19. There is a separate question about the effect of changing the progressivity of the employment tax. If skill formation responds very little to relative wages there is a strong case for a fiscally neutral shift towards greater progressivity, raising the demand for unskilled labour and reducing it for skilled (Layard, Nickell and Jackman, Sections 6.5 and 10.3). 
TABLE 1

Unemployment Rates, Total, Long-Term and Short-Term (\%)

\begin{tabular}{|c|c|c|c|c|c|c|}
\hline & \multicolumn{3}{|c|}{$1983-88$} & \multicolumn{3}{|c|}{$1989-94$} \\
\hline & Total & Long-Term & $\begin{array}{l}\text { Short- } \\
\text { Term }\end{array}$ & Total & Long-Term & $\begin{array}{l}\text { Short- } \\
\text { Term }\end{array}$ \\
\hline Belgium & 11.3 & 8.0 & 3.3 & 8.1 & 5.1 & 2.9 \\
\hline Denmark & 9.0 & 3.0 & 6.0 & 10.8 & 3.0 & 7.9 \\
\hline France & 9.8 & 4.4 & 5.4 & 10.4 & 3.9 & 6.5 \\
\hline Germany & 6.8 & 3.1 & 3.7 & 5.4 & 2.2 & 3.2 \\
\hline Ireland & 16.1 & 9.2 & 6.9 & 14.8 & 9.4 & 5.4 \\
\hline Italy & 6.9 & 3.8 & 3.1 & 8.2 & 5.3 & 2.9 \\
\hline Netherlands & 10.5 & 5.5 & 5.0 & 7.0 & 3.5 & 3.5 \\
\hline Portugal & 7.6 & 4.2 & 3.5 & 5.0 & 2.0 & 3.0 \\
\hline Spain & 19.6 & 11.3 & 8.4 & 18.9 & 9.7 & 9.1 \\
\hline UK & 10.9 & 5.1 & 5.8 & 8.9 & 3.4 & 5.5 \\
\hline Australia & 8.4 & 2.4 & 5.9 & 9.0 & 2.7 & 6.2 \\
\hline N.Zealand & 4.9 & 0.6 & 4.3 & 8.9 & 2.3 & 6.6 \\
\hline Canada & 9.9 & 0.9 & 9.0 & 9.8 & 0.9 & 8.9 \\
\hline USA & 7.1 & 0.7 & 6.4 & 6.2 & 0.6 & 5.6 \\
\hline Japan & 2.7 & 0.4 & 2.2 & 2.3 & 0.4 & 1.9 \\
\hline Austria & 3.6 & n.k. & n.k. & 3.7 & n.k. & n.k. \\
\hline Finland & 5.1 & 1.0 & 4.0 & 10.5 & 1.7 & 8.9 \\
\hline Norway & 2.7 & 0.2 & 2.5 & 5.5 & 1.2 & 4.3 \\
\hline Sweden & 2.6 & 0.3 & 2.3 & 4.4 & 0.4 & 4.0 \\
\hline Switzerland & 0.8 & 0.1 & 0.7 & 2.3 & 0.5 & 1.8 \\
\hline
\end{tabular}


Sources and Notes to Table 1

Source: Total: OECD Standardised rates except for Italy (which is the US BLS measure)

Long-Term: Total times share of long-term in total (as in OECD Employment Outlook, appendix).

Note: Long-term means over 1 year. 


\section{TABLE 2}

\section{Explanatory Variables}

When variable changes between the two sub-periods, the first number is for 1983-88 and the second for 1989-94.

\begin{tabular}{|c|c|c|c|c|c|c|c|c|}
\hline & \multicolumn{2}{|c|}{$\begin{array}{l}\text { Replacement } \\
\text { Rate }\end{array}$} & \multicolumn{2}{|c|}{$\begin{array}{l}\text { Benefit } \\
\text { Duration }\end{array}$} & \multicolumn{2}{|c|}{ ALMP } & \multicolumn{2}{|c|}{$\begin{array}{c}\text { Union } \\
\text { Coverage }\end{array}$} \\
\hline Belgium & 60 & & 4 & & 10.0 & 14.6 & 3 & \\
\hline Denmark & 90 & & 2.5 & & 10.6 & 10.3 & 3 & \\
\hline France & 57 & & 3.75 & 3 & 7.2 & 8.8 & 3 & \\
\hline Germany & 63 & & 4 & & 12.9 & 25.7 & 3 & \\
\hline Ireland & 50 & 37 & 4 & & 9.2 & 9.1 & 3 & \\
\hline Italy & 2 & 20 & 0.5 & & 10.1 & 10.3 & 3 & \\
\hline Netherlands & 70 & & 4 & 2 & 4.0 & 6.9 & 3 & \\
\hline Portugal & 60 & 65 & 0.5 & 0.8 & 5.9 & 18.8 & 3 & \\
\hline Spain & 80 & 70 & 3.5 & & 3.2 & 4.7 & 3 & \\
\hline UK & 36 & 38 & 4 & & 7.8 & 6.4 & 3 & 2 \\
\hline Australia & 39 & 36 & 4 & & 4.1 & 3.2 & 3 & \\
\hline New Zealand & 38 & 30 & 4 & & 15.4 & 6.8 & 2 & \\
\hline Canada & 60 & 59 & 0.5 & 1 & 6.3 & 5.9 & 2 & \\
\hline USA & 50 & & 0.5 & & 3.9 & 3.0 & 1 & \\
\hline Japan & 60 & & 0.5 & & 5.4 & 4.3 & 2 & \\
\hline Austria & 60 & 50 & 4 & & 8.7 & 8.3 & 3 & \\
\hline Finland & 75 & 63 & 4 & 2 & 18.4 & 16.4 & 3 & \\
\hline Norway & 65 & & 1.5 & & 9.5 & 14.7 & 3 & \\
\hline Sweden & 80 & & 1.2 & & 59.5 & 59.3 & 3 & \\
\hline Switzerland & 70 & & 1 & & 23.0 & 8.2 & 2 & \\
\hline
\end{tabular}


Table 2 continued

\begin{tabular}{|c|c|c|c|c|c|}
\hline \multirow[b]{2}{*}{ Belgium } & $\begin{array}{c}\text { Union } \\
\text { Coordination }\end{array}$ & $\begin{array}{c}\text { Employer } \\
\text { Coordination }\end{array}$ & \multirow{2}{*}{$\begin{array}{c}\begin{array}{c}\text { Employment } \\
\text { Protection }\end{array} \\
17\end{array}$} & \multicolumn{2}{|c|}{$\begin{array}{l}\text { Change in } \\
\text { Inflation }\end{array}$} \\
\hline & 2 & 2 & & -0.76 & -0.52 \\
\hline Denmark & 3 & 3 & 5 & -0.86 & -0.46 \\
\hline France & 2 & 2 & 14 & -1.38 & -0.30 \\
\hline Germany & 2 & 3 & 15 & -0.34 & -0.04 \\
\hline Ireland & 1 & 1 & 12 & -1.52 & -0.54 \\
\hline Italy & 2 & 2 & 20 & -1.68 & -0.52 \\
\hline Netherlands & 2 & 2 & 9 & -0.14 & 0.14 \\
\hline Portugal & 2 & 2 & 18 & -2.74 & -1.28 \\
\hline Spain & 2 & 1 & 19 & -1.24 & -0.60 \\
\hline UK & 1 & 1 & 7 & 0.16 & -1.02 \\
\hline Australia & 2 & 1 & 4 & 0.02 & -1.24 \\
\hline New Zealand & 2 & 1 & 2 & 0.36 & -1.22 \\
\hline Canada & 1 & 1 & 3 & -0.08 & -0.84 \\
\hline USA & 1 & 1 & 1 & -0.04 & -0.48 \\
\hline Japan & 2 & 2 & 8 & -0.20 & -0.36 \\
\hline Austria & 3 & 3 & 16 & -0.46 & 0.06 \\
\hline Finland & 3 & 3 & 10 & -0.26 & -0.72 \\
\hline Norway & 3 & 3 & 11 & -0.34 & -1.12 \\
\hline Sweden & 3 & 3 & 13 & -0.75 & -1.02 \\
\hline Switzerland & 1 & 3 & 6 & -0.12 & -0.50 \\
\hline
\end{tabular}


Sources to Table 2

Replacement rate and benefit duration: Mainly US Department of Health and Social Services, Social Security Programmes throughout the World, 1985 and 1993. See LNJ Annex 1.3

ALMP: OECD Employment Outlook, 1988 and 1995. For the first sub-period the data relate to 1987 and for the second to 1991 . We include all active spending, except on the disabled.

Union coverage - union coordination and employer coordination: See LNJ Annex 1.4 and OECD Employment Outlook 1994 pp.175185.

Employment protection: OECD Jobs Study (1994) Part II Table 6.7 Col.5 p.74. Country ranking with 20 as the most strictly regulated.

Inflation: OECD Economic Outlook 


\section{TABLE 3}

\section{Regressions to Explain log Unemployment Rate (\%) (20 OECD Countries, 1983-8 and 1989-94)}

\begin{tabular}{|c|c|c|c|c|c|c|}
\hline \multirow[b]{2}{*}{ Replacement Rate (\%) } & \multicolumn{2}{|c|}{$\begin{array}{c}\text { Total } \\
\text { unemployment } \\
(1)\end{array}$} & \multicolumn{2}{|c|}{$\begin{array}{c}\text { Long-term } \\
\text { unemployment } \\
(2)\end{array}$} & \multicolumn{2}{|c|}{$\begin{array}{c}\text { Short-term } \\
\text { unemployment } \\
(3)\end{array}$} \\
\hline & 0.011 & (1.6) & 0.004 & $(0.5)$ & 0.009 & $(1.2)$ \\
\hline Benefit Duration (yrs) & 0.09 & $(1.3)$ & 0.16 & $(1.9)$ & 0.04 & $(0.6)$ \\
\hline $\operatorname{ALMP}(\%)$ & -0.008 & $(0.7)$ & -0.03 & $(2.0)$ & -0.0008 & $(0.07)$ \\
\hline Union Coverage (1-3) & 0.66 & $(2.7)$ & 0.56 & $(1.7)$ & 0.54 & $(2.2)$ \\
\hline Coordination (1-3) & -0.68 & $(3.2)$ & -0.29 & $(0.9)$ & -0.57 & $(2.4)$ \\
\hline Employment Protection (1-20) & -0.005 & $(0.2)$ & 0.09 & $(2.7)$ & -0.04 & $(1.6)$ \\
\hline $\begin{array}{l}\text { Change in Inflation } \\
\text { (\% points p.a.) }\end{array}$ & -0.17 & $(1.7)$ & -0.13 & $(1.1)$ & -0.15 & $(1.6)$ \\
\hline Constant & -3.96 & $(7.3)$ & -3.28 & $(2.9)$ & -3.8 & $(7.0)$ \\
\hline Dummy for 89-94 & 0.16 & (1.9) & 0.1 & $(0.9)$ & 0.16 & $(2.1)$ \\
\hline Log (Short-Term Unemployment) & \multicolumn{2}{|c|}{ - } & 0.94 & $(4.0)$ & \multicolumn{2}{|c|}{-} \\
\hline $\mathrm{R}^{2}$ & \multicolumn{2}{|c|}{0.59} & \multicolumn{2}{|c|}{0.81} & \multicolumn{2}{|c|}{0.41} \\
\hline s.e. & \multicolumn{2}{|c|}{0.51} & \multicolumn{2}{|c|}{0.59} & \multicolumn{2}{|c|}{0.52} \\
\hline $\mathrm{N}$ & \multicolumn{2}{|c|}{40} & \multicolumn{2}{|c|}{38} & \multicolumn{2}{|c|}{38} \\
\hline
\end{tabular}

\section{Dependent Variables:}

(1) Total unemployed as \% of labour force.

(2) Long-term unemployed (over 1 year) as \% of labour force.

(3) Short-term unemployed (under 1 year) as $\%$ of labour force.

t-statistics in brackets. These are based on the method of 'random effects'.

Notes: (i) ALMP is measured by current active labour market spending as \% of GDP divided by current unemployment. To handle problems of endogeneity and measurement error this is instrumented by active labour market spending in 1987 as \% of GDP divided by average unemployment rate 1977-9.

(ii) The coefficients measure the proportional effect on unemployment of a unit change in an independent variable, where the unit is measured as in Table 2. 